\title{
PENGEMBANGAN ATTITUDE E-ASSESSMENT PADA PEMBELAJARAN MATEMATIKA SEKOLAH MENENGAH ATAS
}

\author{
Teguh Permadi ${ }^{1}$, Mustangin $^{2}$, Sikky El Walida ${ }^{3}$ \\ ${ }^{1,2,3)}$ Program Studi Pendidikan Matematika FKIP Universitas Islam Malang \\ ${ }^{1)}$ tguh.permadi@gmail.com, ${ }^{2}$ must_tangin9@yahoo.co.id, ${ }^{3)}$ sikkywalida@yahoo.co.id
}

\begin{abstract}
Mathematics has important roles in forming the students' character at school. At least, there are nine characters' value which can be formed through learning mathematics, there are: religious, disciplined, honest, hard working, creative, curiosity, independent, communicative, and responsibility. Therefore, teachers need a means to assess those characters. Technology can be used as a means or tool in the assessment of learning, this term is referred as e-assessment. Originating from an idea for combining between assessing the attitude and using the e-assessment, the researcher developed the attitude eassessment. The purpose of this research is to produce the attitude e-assessment in teaching Mathematics at high school. This study is a part of developing research which used 4D model as the development basis that cover define stages, design, develop, and disseminate. The result of the analysis which is conducted to the practitioners, learning evaluation expert, and instructional media expert, the product of e-assessment got 3,34 which means that it is valid. While the analysis result of users' respond which is conducted to 10 students grade X of Madrasah Aliyah Negeri Kota Batu, the eassessment product got 3,32 which means that its valid. Based on those tests, the attitude e-assessment products in the high school mathematics teaching has been declared valid or proper.
\end{abstract}

Keywords: Character Education, E-Assessment, Mathematics

\section{PENDAHULUAN}

Berdasarkan tujuan pendidikan nasional dalam Undang-Undang Republik Indonesia Nomor 20 Tahun 2003 tentang Sistem Pendidikan Nasional pasal 3, maka sekolah diberikan mandat oleh undang-undang tersebut untuk menghasilkan siswa yang berkualitas. Berkualitas artinya tidak hanya sebatas dalam hal pengetahuan dan keterampilan saja, tetapi juga berkualitas dalam berkarakter, sehingga krisis moral yang melanda Indonesia dapat teratasi dengan semaksimal mungkin. John Dewey (dalam Mu'in, 2011:297) berkata bahwa sudah merupakan hal lumrah dalam teori pendidikan bahwa pembentukan watak merupakan tujuan umum pengajaran dan pendidikan budi pekerti di sekolah.

Untuk menerapkan pendidikan karakter di sekolah, maka nilai-nilai karakter tersebut harus diintegrasikan dengan semua mata pelajaran di sekolah. Berdasarkan hal tersebut maka mata pelajaran Matematika ikut bertanggung jawab untuk membentuk karakter siswa. Sedangkan untuk mengimplementasikan pendidikan karakter dalam mata pelajaran matematika, seorang guru wajib untuk menyiapkan perangkat pembelajaran yang diperlukan. Salah satu dari perangkat tersebut adalah perangkat penilaian atau assessment. Uno \& Koni (2012:v) menyatakan bahwa assessment pembelajaran ini meliputi bagaimana cara melakukan penilaian, bagaimana prosedur penilaian, pengolahan data, penetapan skor hingga pelaporannya sehingga gambaran dari hasil pembelajaran yang dilaksanakan oleh guru selama ini dapat diketahui bukan hanya oleh siswa, tetapi juga oleh semua pihak termasuk orang tua dan sekolah. Karena tujuan dari pelaksanaan penilaian adalah guru 
dapat mengetahui seberapa jauh siswanya dapat mencapai tingkat kompetensi yang dipersyaratkan, baik selama mengikuti pembelajaran atau setelahnya (Uno \& Koni, 2012:4).

Selain guru harus mempersiapkan penilaian aspek pengetahuan pada mata pelajaran matematika, guru juga harus melakukan penilaian pada aspek sikap. Ini dilakukan untuk mengetahui seberapa maksimal proses pembelajaran matematika yang telah diintegrasikan dengan konsep pendidikan karakter. Untuk mempermudah sebuah kegiatan penilaian maka guru dapat menggunakan teknologi yang ada di sekitarnya. Pemanfaatan teknologi dalam kegiatan penilaian ini dikenal dengan istilah e-assessment.

\section{KAJIAN TEORI Matematika Berkarakter}

Berdasarkan Peraturan Menteri Pendidikan Nasional Nomor 22 Tahun 2006 tentang Standar Isi, pada poin kelima tujuan mata pelajaran matematika dapat ditarik kesimpulan bahwa, pembelajaran matematika tidak hanya melatih siswa agar mahir berhitung atau memecahkan masalah saja, tetapi melalui pembelajaran matematika diharapkan siswa memiliki rasa ingin tahu, perhatian, dan minat untuk mempelajari matematika serta memiliki sikap ulet dan percaya diri. Hal ini penting karena sebagai mata pelajaran pokok di sekolah, sudah seharusnya apabila matematika ikut mendukung terbentuknya karakter positif pada siswa.

Menurut Rahmi (2013:36) ada delapan nilai karakter yang dapat dikembangkan melalui pembelajaran matematika. Delapan nilai karakter tersebut meliputi: disiplin, jujur, kerja keras, kreatif, rasa ingin tahu, mandiri, komunikatif, dan tanggung jawab. Nilai-nilai karakter tersebut diambil berdasarkan karakteristik ketika siswa mempelajari matematika.

Pembelajaran matematika dapat membentuk karakter disiplin dan jujur pada siswa, karena matematika erat kaitannya dengan ketentuan, aturan, konsep, dan pola, yang tidak boleh dilanggar. Oleh karena itu maka ketika mempelajari matematika, siswa diharapkan dapat bekerja secara tertib dan teratur dalam menggunakan aturan dan konsep tersebut. Selain itu, melalui pembelajaran matematika juga dapat membentuk karakter jujur terhadap apa yang diperoleh siswa. Misalnya, apabila siswa berlaku tidak jujur atau berpura-pura paham tentang materi dipelajari maka siswa tersebut akan rugi, karena setiap materi satu dengan yang lain memiliki keterkaitan.

Matematika erat kaitannya dengan rumus-rumus dan persoalan-persoalan, jadi apabila siswa tidak teliti, tekun, atau mudah putus asa maka siswa tersebut tidak akan pernah mampu menyelesaikan persoalan tersebut. Berdasar hal tersebut maka, pembelajaran matematika juga dapat melatih siswa untuk memiliki karakter kerja keras. Selain itu, dalam menyelesaikan persoalan matematika kadang memerlukan cara yang panjang dan kadang hanya memerlukan cara yang singkat. Oleh karenanya maka, seseorang yang mempelajari matematika dilatih untuk memiliki karakter kreatif, sehingga orang tersebut dapat memilih cara yang efektif agar dapat menyelesaikan persoalan tersebut.

Selama mempelajari matematika, siswa diajarkan untuk senantiasa memiliki karakter tanggung jawab. Hal ini disebabkan ketika siswa membuktikan teorema. Langkah-langkah pembuktian teorema tersebut harus berdasarkan definisi atau aturan-aturan yang telah disepakati bersama. Jadi apabila dalam membuktikan teorema tersebut tidak berdasarkan definisi atau aturan yang telah ada, maka pembuktian akan salah. Sedangkan, apabila siswa dihadapkan dengan suatu persoalan matematika, yang menuntut siswa untuk dapat menyelesaikan persoalan itu dengan tidak banyak tergantung pada bantuan orang lain, maka siswa dilatih untuk dapat bekerja secara mandiri, khususnya dalam hal mengerjakan pekerjaan individu.

Apabila siswa dihadapkan dengan persoalan matematika yang menantang, maka siswa tersebut dituntut untuk menggali informasi dari berbagai sumber agar dapat digunakan untuk menyelesaikan persoalan tersebut. Tuntutan tersebut akan melatih siswa untuk memiliki karakter rasa ingin tahu pada dirinya, yang akan memberikan semangat baginya untuk terus mempelajari matematika. Selain itu, matematika juga merupakan bahasa simbol. Jadi siapa pun yang mempelajari matematika, orang tersebut harus dapat mengomunikasikan bahasa tersebut agar mudah dipahami oleh orang lain. Berdasarkan hal tersebut, maka ketika mempelajari matematika siswa diajarkan untuk berkarakter komunikatif, sehingga dapat menyampaikan apa yang telah dipelajari baik dalam bentuk tulisan maupun lisan. 


\section{Penilaian Sikap}

Penilaian sikap dapat dilakukan dengan berbagai macam teknik. Teknik-teknik tersebut antara lain adalah observasi, penilaian diri sendiri, dan penilaian teman sejawat. Observasi merupakan kegiatan pengamatan yang dilakukan oleh guru terhadap kecenderungan siswa ketika berbuat sesuatu. Teknik penilaian diri sendiri merupakan teknik yang meminta siswa untuk mengemukakan kelebihan dan kekurangan yang dimilikinya. Teknik penilaian diri menuntut siswa untuk berlaku jujur, sehingga hasil yang diperoleh sesuai dengan keadaan asli dari siswa yang bersangkutan. Penilaian antar teman atau yang biasa disebut dengan penilaian teman sejawat, merupakan teknik penilaian yang meminta siswa untuk saling menilai sikap yang ditunjukan oleh temannya. Teknik penilaian antar teman dapat digunakan oleh guru sebagai pembanding dari hasil penilaian diri sendiri yang telah dilakukan siswa.

\section{E-Assessment}

Menurut Joint Information System Committee (2007:6) mendefinisikan E-Assessment sebagai proses penilaian elektronik dimana teknologi komputer digunakan untuk penyajian kegiatan penilaian, dan menyimpan respon atau jawaban. Ini meliputi proses penilaian dari sudut pandang siswa, guru, lembaga pendidikan, dan lembaga penghargaan atau pengatur kebijakan, dan masyarakat umum. Sedangkan pengertian E-Assessment menu-rut Geoffrey Crisp (2011:5) dapat dilakukan dengan banyak perangkat, seperti komputer atau laptop, dengan perangkat komunikasi portabel seperti ponsel pintar, dengan perangkat digital seperti iPads atau melalui perangkat game elektronik. Berdasarkan dua definisi yang telah dijelaskan tersebut, maka yang dimaksud dengan E-Assessment adalah proses penilaian elektronik dimana teknologi seperti komputer atau laptop, ponsel pintar, iPads atau perangkat game elektronik, dapat digu-nakan untuk menyajikan kegiatan penilaian dan menyimpan respon atau jawaban.

E-Assessment menawarkan banyak kelebihan atau keuntungan bagi guru, siswa, ataupun lembaga ketika meng-gunakannya (Crisp, 2011:7). Kelebihan yang dimaksud meliputi empat hal pokok, yaitu efisiensi, efektifitas, keaslian, dan keterlibatan. Kelebihan dari segi efisiensi meliputi: (1) pelaksanaan yang terjadwal, artinya kapan penilaian dilakukan dan kapan penilaian diakhiri dapat diatur sesuai dengan keinginan guru, (2) laporan, artinya ketika penilaian selesai dilakukan maka hasil dari penilaian tersebut dapat langsung dilaporkan kepada siapa pun yang berke-pentingan dengan penilaian tersebut, misalnya sekolah, orang tua, atau yang lainnya, (3) respon yang otomatis, artinya ketika siswa selesai melakukan penilaian maka secara otomatis akan mendapatkan jawaban atau respon dari sistem, (4) penyimpanan hasil dan nilai, artinya E-Assessment memiliki kemampuan untuk melakukan penyim-panan terhadap hasil dan nilai. Kelebihan dari segi efektifitas, meliputi: (1) umpan balik yang segera, artinya ketika meng-gunakan E-Assessment siswa dapat langsung mendapatkan umpan balik atas hasil penilaian yang dilakukan, apakah siswa tersebut telah memenuhi standar penilaian ataukah belum, (2) analisis validitas soal, artinya E-Assessment dapat menjadi alat untuk dapat menganalisis validitas soal yang diberikan, (3) tipe soal baru, artinya banyak tipe soal yang dapat digunakan sesuai dengan kebutuhan guru akan penilaian.

Kelebihan dari segi keaslian, meliputi: (1) akses terhadap orang dan sumber, artinya siapa pun yang menggunakan sumber penilaian dari E-Assessment dapat diketahui keasliannya, sehingga tidak akan menimbulkan salah penilaian karena salah orang, (2) dapat didesain sesuai dengan situasi di dunia nyata, artinya walaupun penilaian dilakukan secara elektronik, tetapi pelaksanaannya dapat didesain agar seperti situasi di dunia nyata, (3) dapat mengatur tugas-tugas yang kompleks, artinya $E$ Assessment memungkinkan guru apabila ingin memberikan tugas-tugas yang kompleks kepada siswa. Kelebihan dari segi keterlibatan, meliputi: (1) dapat menggunakan dunia maya, artinya penilaian dapat dilakukan melalui dunia maya, (2) dapat digunakan untuk mereview diri sendiri atau teman, artinya melalui E-Assessment memungkinkan siswa untuk dapat mengoreksi hasil pekerjaannya sendiri, selain itu pekerjaan tersebut juga dapat dikoreksi oleh teman sebaya.

\section{Attitude E-Assessment}

Attitude E-Assessment adalah sebuah aplikasi yang berguna untuk menilai sikap siswa selama mengikuti pembelajaran matematika yang dapat dilakukan secara offline atau online. Aplikasi ini dapat digunakan sebagai media pengumpulan data, pengolah data, dan pelaporan hasil penilaian. Dalam aplikasi ini telah disediakan indikator sikap yang siap digunakan oleh guru. Sikap yang dinilai 
melalui aplikasi ini antara lain: religius, disiplin, jujur, kerja keras, kreatif, rasa ingin tahu, mandiri, komunikatif, dan tanggung jawab.

Teknik penilaian sikap yang digunakan dalam aplikasi ini antara lain: teknik observasi (digunakan oleh guru secara offline atau online), penilaian diri sendiri dan penilaian teman sejawat (digunakan siswa secara online). Kemudian, data nilai akan tersimpan pada database aplikasi dan sistem akan mengolahnya menjadi data deskriptif dari masing-masing siswa, sehingga hasil dari penilaian tersebut dapat mudah dipahami oleh guru maupun siswa. Selain itu, aplikasi ini dapat menjaga kerahasiaan laporan hasil penilaian sikap siswa, sehingga hanya guru dan siswa yang bersangkutan yang dapat mengetahui hasil penilaiannya. Laporan untuk guru memungkinkan guru untuk dapat melihat semua hasil penilaian dari semua siswanya. Sedangkan, laporan untuk siswa hanya memuat deskripsi sikap yang dimilikinya.

\section{METODE PENELITIAN}

Penelitian menggunakan model pengembangan 4-D yang disarankan oleh Thiagarajan, Semmel \& Semmel (dalam Trianto, 2011:94). Model pengembangan 4-D terdiri dari empat tahapan yaitu, define (pendefinisian), design (perancangan), develop (pengembangan),dan disseminate (penyebaran). Pada tahap define peneliti melakukan analisis kebutuhan kepada guru dan siswa serta melakukan kajian-kajian tentang nilai-nilai karakter yang terkandung dalam matematika. Pada tahap design peneliti melakukan perancangan terkait produk yang akan dikembangkan berdasarkan hasil analisis kebutuhan dan kajian-kajian sebelumnya. Pada tahap develop peneliti melakukan pembuatan produk yang diikuti dengan uji coba individu. Kemudian pada tahap terakhir yaitu disseminate, peneliti melakukan uji coba kelompok kecil dilanjutkan dengan melakukan penyebaran produk kepada pihak-pihak terkait. Uji coba individu dilakukan kepada tiga orang validator yaitu praktisi, ahli evaluasi pembelajaran, dan ahli media pembelajaran. Sedangkan uji coba kelompok kecil dilakukan kepada 10 siswa kelas X.

Dalam penelitian ini, instrumen pe-ngumpulan data yang digunakan adalah berupa angket. Angket yang digunakan dalam penelitian ini diklarifikasikan men-jadi empat jenis yaitu: lembar validasi instrumen, angket kebutuhan guru dan siswa, angket penilaian ahli, dan angket respon user. Rumus yang digunakan untuk meng-analisis data kebutuhan guru dan siswa adalah sebagai berikut.

$\mu=\frac{f}{N} \times 100 \%$

(diadaptasi dari Sudjana, 2009:131)

Keterangan:

$P \quad$ : Persentase

$f \quad$ : Jumlah frekuensi jawaban responden terhadap suatu pilihan

$N \quad$ : Jumlah responden

Interpretasi dari hasil analisis data kebutuhan guru dan siswa tersebut tertera dalam Tabel 1. Rumus yang digunakan untuk menganalisis hasil lembar validasi instrumen, angket penilaian ahli, dan angket respon user adalah sebagai berikut.

$S=\frac{\sum X_{i}}{N}$

(diadaptasi dari Sudjana, 2009:109)

Ketarangan:

$S \quad$ : Rata-rata per aspek

$\sum X_{t} \quad$ : Jumlah seluruh skor per item

$N \quad$ : Banyaknya butir item pernyataan 
$K=\frac{\sum S_{1}}{N}$

(diadaptasi dari Sudjana, 2009:109)

Keterangan:

$K \quad$ : Rata-rata semua aspek

$\Sigma S_{i}:$ Jumlah rata-rata seluruh skor per aspek

$N \quad$ : Banyaknya aspek

$N K=\frac{\sum K_{i}}{N}$

(diadaptasi dari Sudjana, 2009:109)

Keterangan:

NK : Rata-rata total dari semua validator/user

$\sum K_{i}:$ Jumlah rata-rata seluruh skor per validator/user

$N \quad$ : Banyaknya validator/user

Sedangkan interpretasi dari hasil analisis lembar validasi instrumen, angket penilaian ahli, dan angket respon user tersebut tertera dalam Tabel 2.

Tabel 1. Interpretasi Hasil Analisis Angket Kebutuhan Guru dan Siswa

\begin{tabular}{|c|c|c|}
\hline Persentase (\%) & Kriteria & Interpretasi \\
\hline $90-99$ & Sangat butuh & $\begin{array}{l}\text { Guru dan siswa sangat membutuhkan } \\
\text { pengembangan produk attitude e-assessment. }\end{array}$ \\
\hline $80-89$ & Butuh & $\begin{array}{l}\text { Guru dan siswa membutuhkan pengembangan } \\
\text { produk attitude e-assessment. }\end{array}$ \\
\hline $70-79$ & Cukup butuh & $\begin{array}{l}\text { Guru dan siswa cukup membutuhkan } \\
\text { pengembangan produk attitude e-assessment. }\end{array}$ \\
\hline $60-69$ & Kurang butuh & $\begin{array}{l}\text { Guru dan siswa kurang membutuhkan } \\
\text { pengembangan produk attitude e-assessment. }\end{array}$ \\
\hline$<60$ & Tidak butuh & $\begin{array}{l}\text { Guru dan siswa tidak membutuhkan } \\
\text { pengembangan produk attitude e-assessment. }\end{array}$ \\
\hline
\end{tabular}

(diadaptasi dari Sudjana, 2009:118)

Tabel 2. Interpretasi Hasil Analisis Lembar Validasi Angket Penilaian Ahli, dan Angket Respon User

\begin{tabular}{|c|c|c|}
\hline Rata-Rata & Kriteria & Keputusan \\
\hline $3 \leq \mathrm{NK} \leq 4$ & Valid & $\begin{array}{l}\text { Produk dinyatakan valid atau tepat, tanpa memerlukan } \\
\text { revisi. }\end{array}$ \\
\hline $2 \leq \mathrm{NK}$ & Kurang Valid & $\begin{array}{l}\text { Produk dinyatakan kurang valid atau kurang tepat, } \\
\text { dengan memerlukan sedikit revisi. }\end{array}$ \\
\hline $1 \leq \mathrm{NK}$ & Tidak Valid & $\begin{array}{l}\text { Produk dinyatakan tidak valid atau tidak tepat, dengan } \\
\text { memerlukan banyak revisi. }\end{array}$ \\
\hline
\end{tabular}




\section{PEMBAHASAN}

Berdasarkan analisis peneliti terhadap hasil lembar validasi instrumen angket kebutuhan guru dan siswa, angket penilaian ahli, dan angket respon user, maka didapatkan kesimpulan bahwa, angket kebutuhan guru dan siswa mendapatkan nilai 2,9 dan 2,9 yang bermakna bahwa angket tersebut memerlukan sedikit revisi, sedangkan angket penilaian ahli dan angket respon user mendapatkan nilai 3,$3 ; 3,2 ; 3,2$; dan 3,2 yang bermakna bahwa angket tersebut tidak memerlukan revisi. Analisis terhadap hasil angket kebutuhan guru dan siswa, peneliti mendapatkan kesimpulan bahwa rata-rata $90 \%$ guru dinyatakan sangat butuh dan $87,3 \%$ siswa dinyatakan butuh pengembangan produk attitude e-assessment.

Analisis terhadap hasil uji coba individu yang dilakukan kepada praktisi, ahli evaluasi pembelajaran, dan ahli media pembelajaran didapatkan kesimpulan bahwa produk attitude $e$ assessment mendapatkan nilai rata-rata sebesar 3,34 yang bermakna bahwa produk yang dihasilkan telah valid tanpa memerlukan revisi. Sedangkan analisis yang dilakukan berdasarkan hasil uji coba kelompok kecil mendapatkan kesimpulan bahwa produk attitude e-assessment mendapatkan nilai rata-rata sebesar 3,32 yang bermakna bahwa produk yang dihasilkan telah valid tanpa memerlukan revisi. Analisis terhadap hasil lembar validasi angket termuat dalam Tabel 3, sedangkan analisis terhadap hasil uji coba individu dan uji coba kelompok kecil termuat dalam Tabel 4 dan Tabel 5. Adapun produk attitude e-assessment yang didapatkan dari hasil penelitian pengembangan ini tertera dalam Gambar 1, Gambar 2, dan Gambar 3.

Tabel 3. Hasil Lembar Validasi Instrumen

\begin{tabular}{llcccccc}
\hline \multirow{2}{*}{ No } & \multirow{2}{*}{ Aspek yang dinilai } & $\mathrm{I}_{1}$ & $\mathrm{I}_{2}$ & $\mathrm{I}_{3}$ & $\mathrm{I}_{4}$ & $\mathrm{I}_{5}$ & $\mathrm{I}_{6}$ \\
\cline { 3 - 8 } & & & & & & & \\
\hline 1 & Kelayakan isi & 2,5 & 3 & 3,5 & 3 & 3,5 & 3,5 \\
2 & Ketercapaian tujuan & 2,5 & 2,5 & 3,5 & 3,5 & 3,5 & 3,5 \\
3 & Format & 3 & 2,7 & 3,3 & 3,3 & 3 & 3 \\
4 & Kebahasaan & 3 & 3,3 & 3 & 3 & 3 & 3 \\
5 & Kegrafisan & 3,3 & 3,3 & 3,3 & 3,3 & 3,3 & 3 \\
& Rata-rata total & 2,9 & 2,9 & 3,3 & 3,2 & 3,2 & 3,2 \\
\hline
\end{tabular}

Keterangan:

$\mathrm{I}_{1}$ : angket analisis kebutuhan guru

$\mathrm{I}_{2}$ : angket analisis kebutuhan siswa

$\mathrm{I}_{3}$ : angket penilaian praktisi

$\mathrm{I}_{4}$ : angket penilaian ahli evaluasi pembelajaran

$\mathrm{I}_{5}$ : angket penilaian ahli media pembelajaran

$\mathrm{I}_{6}$ : angket penilaian respon user

Tabel 4. Hasil Uji Coba Individu

\begin{tabular}{clccc}
\hline \multirow{2}{*}{ No } & \multirow{2}{*}{ Aspek yang dinilai } & \multicolumn{3}{c}{ Rata-Rata Per Aspek } \\
\cline { 3 - 5 } & & $\mathrm{V}_{1}$ & $\mathrm{~V}_{2}$ & $\mathrm{~V}_{3}$ \\
\hline 1 & Isi dan tujuan & 3,75 & 3,5 & 3,2 \\
2 & Teknis & 3 & 2,3 & - \\
3 & Evaluasi pembelajaran & 3,67 & 3,67 & - \\
4 & Tampilan & - & - & 3,6 \\
\multicolumn{2}{r}{ Rata-Rata Per Validator } & 3,47 & 3,16 & 3,40 \\
& Rata-Rata Semua Validator & \multicolumn{3}{c}{3,34} \\
\hline
\end{tabular}

Keterangan:

$\mathrm{V}_{1}$ : praktisi atau guru $\mathrm{V}_{2}$ : ahli evaluasi pembelajaran $\quad \mathrm{V}_{3}$ : ahli media pembelajaran 
Tabel 5. Hasil Uji Coba Kelompok Kecil

\begin{tabular}{llcccccccccc}
\hline \multirow{2}{*}{ No } & \multirow{2}{*}{ Aspek yang dinilai } & \multicolumn{10}{c}{ Rata-Rata Per Aspek } \\
\cline { 2 - 12 } & $\mathrm{R}_{1}$ & $\mathrm{R}_{2}$ & $\mathrm{R}_{3}$ & $\mathrm{R}_{4}$ & $\mathrm{R}_{5}$ & $\mathrm{R}_{6}$ & $\mathrm{R}_{7}$ & $\mathrm{R}_{8}$ & $\mathrm{R}_{9}$ & $\mathrm{R}_{10}$ \\
\hline 1 & Teknis & 3 & 3,33 & 2,33 & 3 & 3 & 3,33 & 3 & 3 & 2,67 & 3 \\
2 & Evaluasi pembelajaran & 4 & 3,67 & 3 & 3,67 & 4 & 4 & 4 & 3,67 & 3,67 & 3,33 \\
& Rata-rata per user & 3,5 & 3,5 & 2,67 & 3,33 & 3,5 & 3,67 & 3,3 & 3,3 & 3,17 & 3,17 \\
& Rata-rata user & & & \multicolumn{1}{c}{3,32} \\
\hline
\end{tabular}

Keterangan:

$\begin{array}{lllll}\mathrm{R}_{1} \text { : siswa ke-1 } & \mathrm{R}_{3} \text { : siswa ke-3 } & \mathrm{R}_{5} \text { : siswa ke-5 } & \mathrm{R}_{7} \text { : siswa ke-7 } & \mathrm{R}_{9} \text { : siswa ke-9 }\end{array}$

$\begin{array}{lllll}\mathrm{R}_{2} \text { : siswa ke-2 } & \mathrm{R}_{4} \text { : siswa ke-4 } & \mathrm{R}_{6} \text { : siswa ke-6 } & \mathrm{R}_{8} \text { : siswa ke-8 } & \mathrm{R}_{10} \text { : siswa ke-10 }\end{array}$

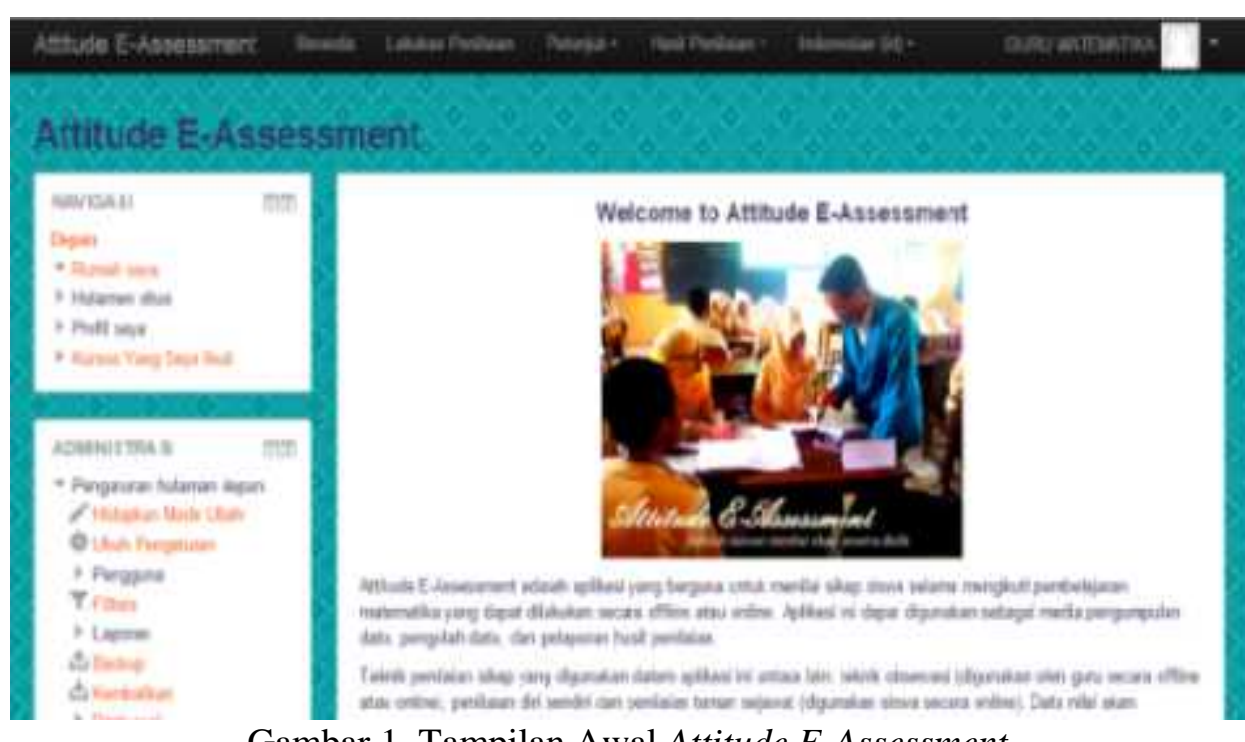

Gambar 1. Tampilan Awal Attitude E-Assessment

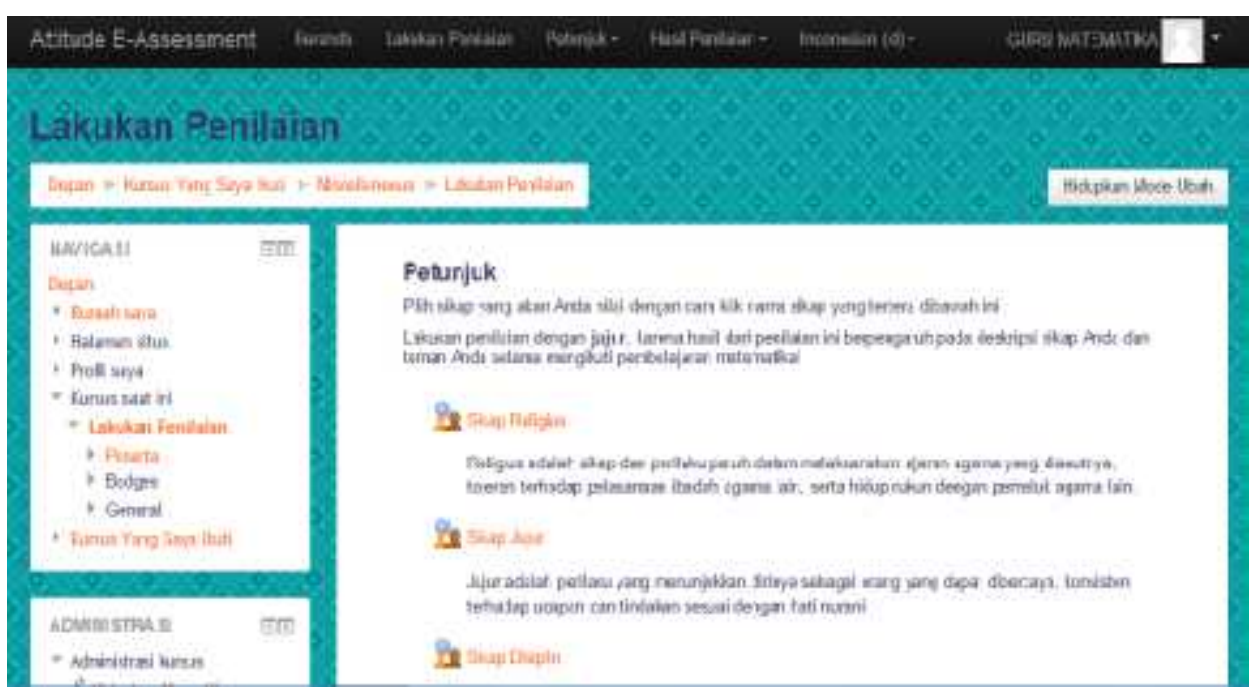

Gambar 2. Halaman Sikap yang dinilai dalam Attitude E-Assessment 


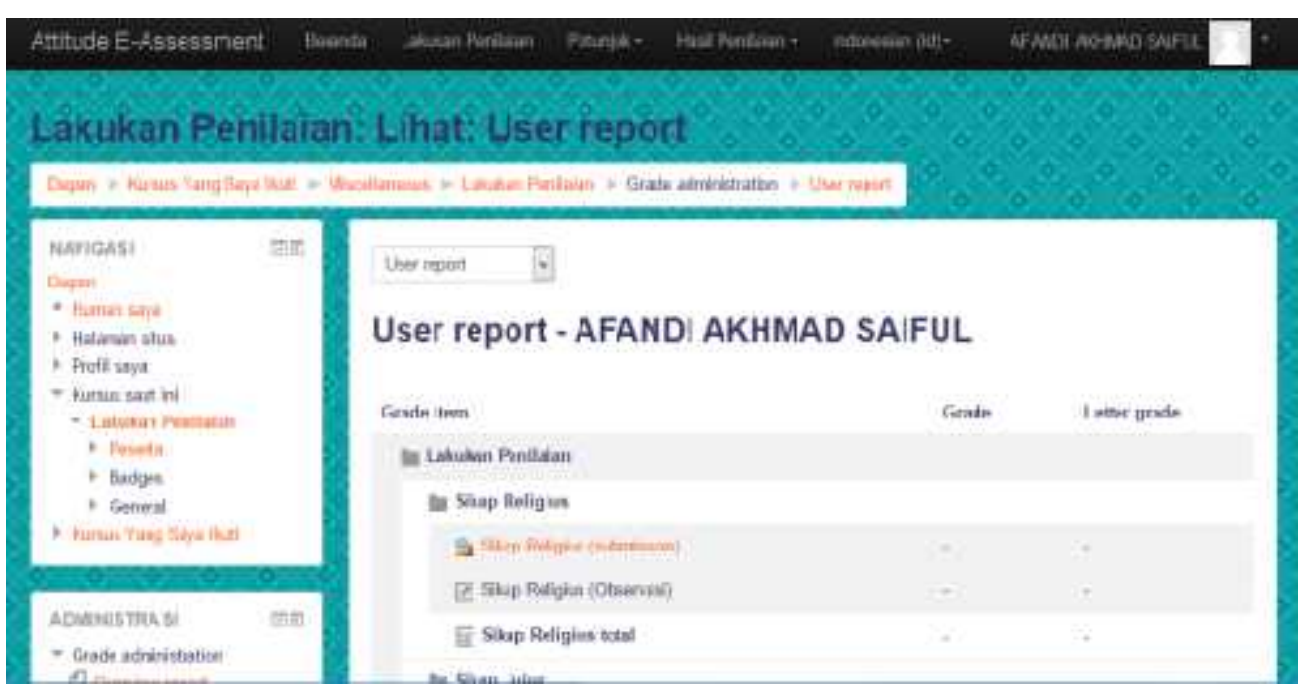

Gambar 3. Halaman Hasil Penilaian Attitude E-Assessment

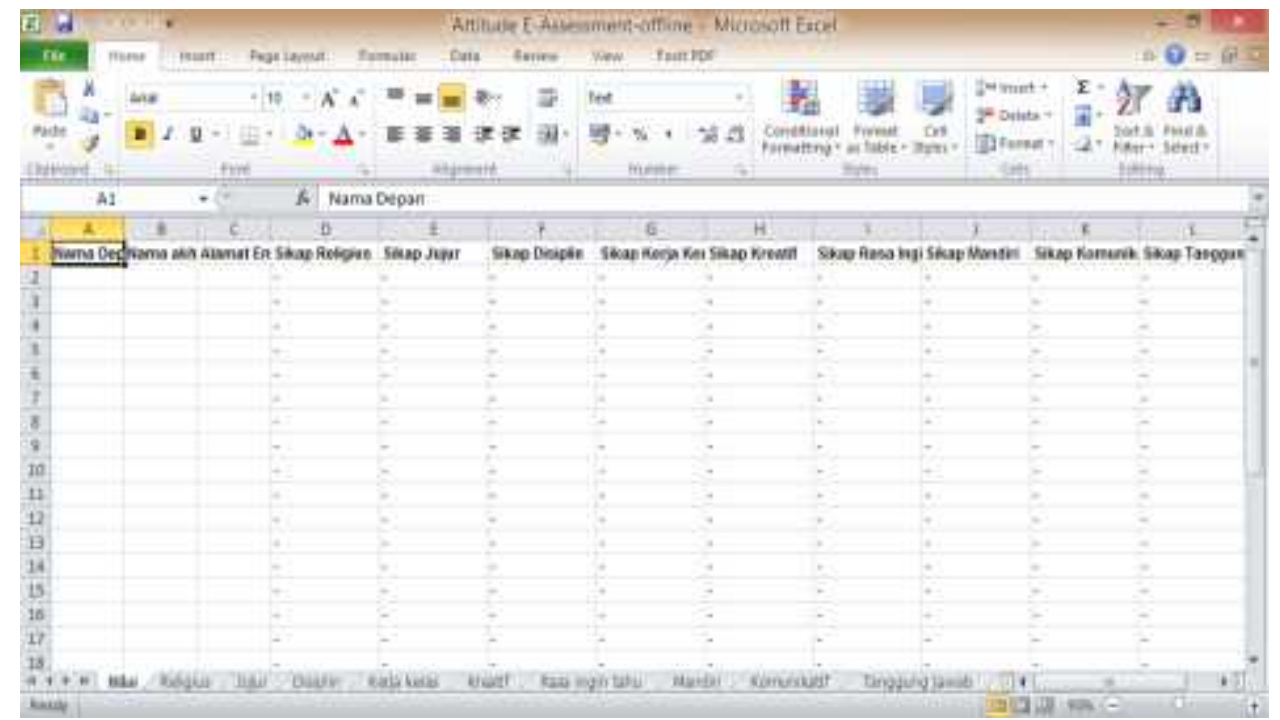

Gambar 4. Attitude E-Assessment Versi Offline

\section{PENUTUP}

Dari hasil penelitian yang dilakukan, secara umum dapat disimpulkan bahwa produk pengembangan attitude e-assessment pada pembelajaran matema-tika sekolah atas dinyatakan valid atau tepat tanpa memerlukan revisi.

\section{DAFTAR RUJUKAN}

Crisp, Geoffrey. 2011. Teacher's Handbook on e-Assessment. Australia: Departemen Pendidikan, Ketenagakerjaan, dan Hubungan Kerja Pemerintah Australia.

Rahmi. 2013. Kontribusi Matematika dalam Pembentukan Karakter Siswa. Jurnal Ekotrans, Vol 12 (1): 31-38.

Mu'in, Fatchul. 2011. Pendidikan Karakter. Sleman: Ar-Ruzz Media.

Sudjana, Nana. 2009. Penilaian Hasil Proses Belajar Mengajar. Bandung: Remaja Rosdakarya.

The Joint Information Systems Committee. 2007. Effective Practice with e-Assessment. Inggris: HEFCE. 
126 Teguh Permadi, Mustangin, Sikky El Walida

Trianto. 2011. Model Pembelajaran Terpadu: Konsep, Strategi, dan Implementasinya dalam Kurikulum Tingkat Satuan Pendidikan (KTSP). Jakarta: Bumi Aksara.

Uno, Hamzah B. and Koni, Satria. 2012. Assessment Pembelajaran. Jakarta: PT Bumi Aksara.

Widoyoko, Eko Putro. 2012. Teknik Penyusunan Instrumen Penelitian. Yogyakarta: Pustaka Belajar. 